\title{
Elevated ammonium concentrations and low light form a dangerous synergy for eelgrass Zostera marina
}

\author{
Beatriz Villazán, Morten F. Pedersen ${ }^{2, *}$, Fernando G. Brun, Juan J. Vergara1 \\ ${ }^{1}$ Departamento de Biología, Area de Ecología, Facultad de Ciencias del mar y Ambientales, Universidad de Cádiz, \\ 11510 Puerto Real, Cádiz, Spain \\ ${ }^{2}$ Department of Environmental, Social and Spatial Change (ENSPAC), Roskilde University, PO Box 260, 4000 Roskilde, \\ Denmark
}

\begin{abstract}
We studied the effect of ecologically relevant ammonium concentrations and light on several morphological and physiological properties, nitrogen metabolism and carbon reserves of eelgrass Zostera marina L. Eelgrass was grown under mesocosm conditions at 3 levels of ammonium enrichment (target concentrations of 0,10 and $25 \mu \mathrm{M}$ ) and 2 levels of light (low and high light). High ammonium supply combined with low light had a negative effect on several morphological and physiological response parameters, while no such effects were found when ammonium was supplied under high light. $\mathrm{N}$ enrichment caused an increase in the content of total $\mathrm{N}$, intracellular ammonium, free amino acids and residual $\mathrm{N}$ in the plants and this response was more pronounced under low-light conditions than under high light. The soluble proteins content decreased, in contrast with external ammonium enrichment. The accumulation of free amino acids and residual $\mathrm{N}$ in $\mathrm{NH}_{4}{ }^{+}$-enriched plants was followed by a substantial drop in carbohydrate reserves (sucrose and starch), which was larger in plants grown under low-light conditions. Our results indicate that $\mathrm{N}$ enrichment increases the demand for $\mathrm{C}$ skeletons and energy, and that photosynthesis cannot supply enough $\mathrm{C}$ and energy to cover that demand under low-light conditions. Eelgrass plants exposed to reduced light conditions, for example close to their depth limit or when covered by drift macroalgae, may thus be especially susceptible to enhanced ammonium concentrations. Our study demonstrates that ammonium toxicity may explain why eelgrass and other seagrasses deteriorate under nutrient-rich, low-light conditions.
\end{abstract}

KEY WORDS: Dissolved inorganic nitrogen - Light · Nitrogen metabolism - Carbon reserves · Seagrass $\cdot$ Eutrophication

\section{INTRODUCTION}

Seagrasses are the dominant benthic primary producers in many coastal areas and they provide many ecologically and economically important services to marine ecosystems (Costanza et al. 1997, Duarte 2000, Waycott et al. 2009). Seagrass ecosystems have declined worldwide over the last 4 to 5 decades (Orth et al. 2006, Waycott et al. 2009, Short et al. 2011) as a consequence of increasing anthropogenic nutrient loading and subsequent eutrophication (Short et al. 1995, Short \& Wyllie-Echevarria 1996, Burkholder et al. 2007). High nutrient availability affects seagrasses in several ways. The major effects are indirectly caused by the proliferation of phytoplankton, epiphytic microalgae and fast-growing drifting macroalgae promoting light attenuation (Sand-Jensen \& Borum 1991, Hernández et al. 1997, Valiela et al. 1997, Hauxwell et al. 2001, McGlathery 2001, Bryars et al. 2011, Lyons et al. 2012) or increasing the sedi- 
ment organic matter load, which may reduce oxygen levels and increase the risk of anoxia (Greve et al. 2003) and sulfide intrusion into the plants (Holmer \& Bondgaard 2001, Borum et al. 2005, Pérez et al. 2007, Olivé et al. 2009). Furthermore, there may be a direct effect of high nutrient availability on seagrasses since exposure to high concentrations of $\mathrm{NH}_{4}{ }^{+} \mathrm{can}$ be toxic to higher plants (e.g. Marschener 1995, Britto \& Kronzucker 2002, Brun et al. 2002, 2008).

A moderate increase in the availability of inorganic nitrogen $(<10 \mu \mathrm{M})$ may stimulate growth and biomass of seagrasses when these are growing under nutrient-limited conditions (e.g. Orth 1977, Alcoverro et al. 1997, Peralta et al. 2003, Invers et al. 2004). However, some studies have shown little or no effect of nutrient enrichment (e.g. Harlin \& Thorne-Miller 1981, Dennison et al. 1987, Murray et al. 1992, Pedersen \& Borum 1993, Pedersen 1995, Lee \& Dunton 2000), most likely because these studies were carried out in areas with relatively high ambient availability of nutrients where the plants under study were nutrient replete. A growing body of evidence suggests that enrichment by inorganic nitrogen $(\mathrm{N})$, especially $\mathrm{NH}_{4}{ }^{+}$, can have an adverse effect on seagrasses by reducing photosynthesis, growth and survival (e.g. Burkholder et al. 1992, van Katwijk et al. 1997, Brun et al. 2002, 2008, van der Heide et al. 2008, Christianen et al. 2011).

Adverse effects of high $\mathrm{NH}_{4}^{+}$concentrations on seagrasses and other higher plants have traditionally been explained by internal accumulation of $\mathrm{NH}_{4}{ }^{+}$, which may affect internal $\mathrm{pH}$ and enzyme kinetics, uncouple the production of ATP during photosynthesis, increase respiration and reduce the uptake of other cations (e.g. Marschener 1995). Other studies indicate that high $\mathrm{NH}_{4}{ }^{+}$concentrations may cause enhanced ethylene synthesis, increased energy consumption related to active efflux of $\mathrm{NH}_{4}{ }^{+}$, and reduced photo-protection (Britto et al. 2001, Britto \& Kronzucker 2002). The negative effect of high $\mathrm{NH}_{4}{ }^{+}$ availability on plants may also be related to an imbalance in the carbon $(\mathrm{C})$ economy of the plants since accumulation of internal $\mathrm{NH}_{4}{ }^{+}$stimulates the synthesis of amino acids in plants (Marschener 1995). This synthesis requires $\mathrm{C}$ skeletons and energy, which must be provided directly from photosynthesis or be mobilized from $\mathrm{C}$ reserves within the plant. Continuous uptake and assimilation of $\mathrm{NH}_{4}{ }^{+}$can therefore drain the $\mathrm{C}$ reserves and, thus, compete with other $\mathrm{C}$-demanding or energy-consuming metabolic processes.

The aims of this study were to test whether elevated, but ecologically relevant, levels of $\mathrm{NH}_{4}{ }^{+}$affect eelgrass fitness and to study the underlying mechanisms behind this toxicity in terms of $\mathrm{N}$ metabolism and the possible consequences for the $\mathrm{C}$ reserves in the plant. We cultivated Zostera marina plants under 3 different $\mathrm{NH}_{4}{ }^{+}$concentrations $(0,10$ and $25 \mu \mathrm{M})$ at 2 different light levels (low and high) for $5 \mathrm{wk}$. We hypothesized that increasing concentrations of $\mathrm{NH}_{4}{ }^{+}$ in the growth media would cause increasingly negative effects in $Z$. marina, because $C$ reserves may be drained in order to support the assimilation of $\mathrm{NH}_{4}{ }^{+}$. We expected that low light would enforce and high light alleviate the potential negative effects of $\mathrm{NH}_{4}{ }^{+}$.

\section{MATERIALS AND METHODS}

A 2-factorial culture experiment was conducted from October to November 2011 (ca. 5 wk) to test how $\mathrm{NH}_{4}{ }^{+}$concentrations and light levels affected eelgrass Zostera marina. Individual shoots of $Z$. marina were collected from Isefjorden, Denmark, at a depth of 1-2 $\mathrm{m}$ in late September 2011. Healthy looking shoots with intact rhizomes (6-9 internodes) were transferred to the laboratory where they were held in aerated water from the sampling site under sub-saturating light (ca. $30 \mu \mathrm{mol}$ photons $\mathrm{m}^{-2} \mathrm{~s}^{-1}$ ) in a $16 \mathrm{~h}$ light:8 $\mathrm{h}$ dark cycle at $15^{\circ} \mathrm{C}$ until used in the experiment (ca. $1 \mathrm{wk}$ ). Shoots were first 'standardized' to have 4 (visible) leaves and 4 rhizome internodes (by removing older leaves and internodes) before being used in the experiment. Each of 18 aquaria (volume = 201 l) was filled with ca. 2-3 1 of sediment from the sampling site and $15 \mathrm{l}$ of filtered water from the North Sea. The salinity of the seawater was adjusted to $20 \%$ by dilution with tap water and the temperature was kept constant at $15^{\circ} \mathrm{C}$ to obtain optimal growth conditions for the plants (Nejrup \& Pedersen 2008). The water in the aquaria was aerated to ensure mixing and changed weekly to avoid nutrient limitation and excessive growth of phytoplankton. Light above the aquaria was provided by lamps with halogen spots $(12 \mathrm{~V}, 35 \mathrm{~W})$ in a $16 \mathrm{~h}$ light:8 $\mathrm{h}$ dark cycle.

Fourteen eelgrass plants were planted in each of the 18 aquaria, which were then subjected to 3 target concentrations of $\mathrm{NH}_{4}{ }^{+}(0,10$ and $25 \mu \mathrm{M}$; treatments called $\mathrm{C}_{1}+\mathrm{N}$ and $+\mathrm{NN}$, respectively) and 2 levels of light $\left(26 \pm 3\right.$ and $70 \pm 9 \mu \mathrm{mol}$ photons $\mathrm{m}^{-2} \mathrm{~s}^{-1} \mathrm{PAR}_{\text {; }}$ treatments called LL and HL, respectively) with 3 replicate aquaria within each treatment combination. The light intensity provided in the LL treatment was low, but above the light compensation point $\left(I_{C}\right)$ of Zostera marina, while that provided in the HL treat- 
ment was close to saturating levels $\left(I_{\mathrm{K}}\right)$ (Marsh et al. 1986, Olesen \& Sand-Jensen 1993).

The water added to the aquaria contained low levels of ammonium (ca. $1 \mu \mathrm{M})$ and nitrate $(2-3 \mu \mathrm{M})$, and ammonium was added to the aquaria (in the $+\mathrm{N}$ and $+\mathrm{NN}$ treatments) from a $\mathrm{NH}_{4} \mathrm{Cl}$ stock solution every day to keep the concentrations as close to the target concentrations as possible. The $\mathrm{NH}_{4}{ }^{+}$addition corresponded to $150 \mu \mathrm{mol}$ aquaria ${ }^{-1} \mathrm{~d}^{-1}$ in the $+\mathrm{N}$ treatment and $375 \mu \mathrm{mol}$ aquaria ${ }^{-1} \mathrm{~d}^{-1}$ in the $+\mathrm{NN}$ treatment. The concentration of ammonium was monitored twice weekly in all aquaria. Water samples were collected just before and right after addition of ammonium. The concentrations before adding new ammonium averaged $0.8 \pm 0.2 \mu \mathrm{M}$ in the control treatment, $0.7 \pm 0.2 \mu \mathrm{M}$ in the $+\mathrm{N}$ treatment, and $1.2 \pm 0.2 \mu \mathrm{M}$ in the $+\mathrm{NN}$ treatment (mean $\pm \mathrm{SD}$ across 3 replicate aquaria and over 10 sampling dates in each treatment). The concentration of ammonium just after adding ammonium averaged $0.8 \pm 0.2 \mu \mathrm{M}$ in the control treatment, $11.2 \pm 0.3 \mu \mathrm{M}$ in the $+\mathrm{N}$ treatment, and $24.7 \pm 0.4 \mu \mathrm{M}$ in the $+\mathrm{NN}$ treatment. All water in the aquaria was changed once weekly to prevent accumulation of ammonium (especially in the $+\mathrm{NN}$ treatment) and to reduce the risk of limitation by phosphorus or micronutrients.

\section{Physiological and morphological responses}

Prior to transplantation into the aquaria, each plant was weighed (initial fresh weight biomass) and marked for measuring leaf elongation rate. At the end of the experiment, all surviving plants were harvested and each plant was weighed (fresh weight, FW) and the number of leaves per shoot was counted. Net production ( $\mathrm{g} \mathrm{FW}$ plant ${ }^{-1} \mathrm{~d}^{-1}$ ) was estimated from the net change in individual plant weights over the course of the experiment while the production of new leaves (plastochrone interval) and leaf elongation rate was measured using the leaf-marking technique (Sand-Jensen 1975). The appearance of new sideshoots per original shoot was recorded. Survival rate was estimated from the number of surviving plants in each aquarium at the end of the experiment. Leaf necrosis was quantified as the area with brownblack discolouration of the 3 youngest leaves on each shoot.

Maximum net photosynthetic rate $\left(P_{\max }\right)$ and dark respiration were measured as $\mathrm{O}_{2}$ production or consumption under saturating light conditions (ca. $150 \mu \mathrm{mol}$ photons $\mathrm{m}^{-2} \mathrm{~s}^{-1}$ PAR) or in darkness. Four randomly chosen eelgrass shoots were collected from each aquarium at the end of the experiment and incubated in a $800 \mathrm{ml}$ gas-tight, transparent chamber equipped with a circulation pump (AquaBee, $300 \mathrm{l}$ $\mathrm{h}^{-1}$ ) used to ensure circulation within the chamber. Two shoots were fixed in each chamber, which was filled with natural seawater without ammonium enrichment (salinity $20 \%$ ) having an $\mathrm{O}_{2}$ concentration corresponding to ca. $70 \%$ of air saturation to prevent supersaturation of $\mathrm{O}_{2}$ in the chamber during incubations. The chamber was finally submerged into a water bath with constant temperature $\left(15^{\circ} \mathrm{C}\right)$. The chamber was equipped with a Clark-type $\mathrm{O}_{2}$ microelectrode (OX-500, Unisense) that was connected to a pico-amperemeter (Picoammeter PA2000, Unisense) and a Pico Technology ADC-16 data logger. A lamp with 8 halogen spots (OSRAM Decostar $51 ; 12 \mathrm{~V}, 35 \mathrm{~W}$ ) illuminated the set-up. The water bath held 2 replicate chambers at a time. The $\mathrm{O}_{2}$ concentrations were recorded every minute throughout the incubations and rates of $\mathrm{O}_{2}$ release or uptake were calculated from periods with constant changes in $\mathrm{O}_{2}$ concentration over a minimum of 10-15 min.

\section{Biochemical responses}

\section{Total C and N}

Total $\mathrm{C}$ and $\mathrm{N}$ content were determined on duplicate freeze-dried, ground samples of leaves and roots/rhizomes from each aquarium using a CarloErba NA-1500 CHNS analyzer.

\section{Intracellular inorganic $\mathrm{N}$}

Intracellular concentrations of $\mathrm{NH}_{4}{ }^{+}$and $\mathrm{NO}_{3}^{-}$ were measured on duplicate leaf and rhizome samples from each aquarium. Samples were rinsed in deionized water and ca. $0.5 \mathrm{~g}$ (FW) was ground in $20 \mathrm{ml}$ of boiling deionized water (Dortch et al. 1984). Samples were sonicated for $10 \mathrm{~min}$ and then centrifuged for $20 \mathrm{~min}$ at $5000 \times \mathrm{g}$. The concentration of $\mathrm{NH}_{4}{ }^{+}$and $\mathrm{NO}_{3}{ }^{-}$was finally measured in the supernatant according to Bower \& Holm-Hansen (1980) and Grasshoff et al. (1983).

Free amino acids

Intracellular concentrations of free amino acids (FAA) were measured on duplicate leaf and rhizome samples from each aquarium. Leaves or rhizome 
internodes were cut from the plants and wiped with a piece of cloth to remove attached epiphytes and debris. Samples were transferred to a $20 \mathrm{ml}$ glass vial with $10 \mu \mathrm{l} \mathrm{96 \%} \mathrm{ethanol} \mathrm{for} \mathrm{extraction.} \mathrm{The} \mathrm{extract}$ was then transferred to a $1.5 \mathrm{ml}$ HPLC vial with $70 \mu \mathrm{l}$ $10 \mathrm{mM}$ borate buffer at pH 8.8. Primary and secondary amines in the sample were derivatized with $20 \mu \mathrm{l}$ 10 mM 6-aminoquinolyl- $N$-hydroxysuccinimidyl carbamate (Liu et al. 1995) using a AccQ Tag kit (Waters Corp.). The derivatives were heated to $55^{\circ} \mathrm{C}$ for $10 \mathrm{~min}$ to degrade a tyrosine side product that interferes with the chromatographic separation of amino acids. The derivatives were separated on a Waters Alliance 2695 separation module with a $3.9^{\circ}-150 \mathrm{~mm}$ Nova-Pak C-18 column. The solvents used for the separation were (1) $98.9 \mathrm{mM}$ sodium acetate and $6.34 \mathrm{mM}$ triethylenamine at $\mathrm{pH} 5.70$, (2) $98.9 \mathrm{mM}$ sodium acetate and $6.34 \mathrm{mM}$ triethylenamine at pH 6.80, (3) acetonitrile, and (4) water. The separated amino acid derivatives were quantified by fluorescence (250 $\mathrm{nm}$ excitation and $395 \mathrm{~nm}$ emission) using a Waters 474 scanning fluorescence detector. The detection limit of the method was about 1 pmol of each amino acid. The amount of $\mathrm{N}$ bound in FAA was finally estimated using the specific $C: N$ ratio of each of the identified amino acids.

\section{Soluble proteins}

The content of soluble proteins was determined on duplicate leaf and rhizome samples from each aquarium using a modification of the Bradford method (Jones et al. 1989). Fresh plant material (ca. 0.1 and $0.5 \mathrm{~g}$ for leaf and rhizome samples, respectively) was ground and transferred to a centrifuge tube with $1 \mathrm{ml} 0.1 \mathrm{M} \mathrm{NaOH}(\mathrm{pH}$ 12.8). The mixture was shaken on a vortex mixer and then sonicated for 1-2 min. Samples were left to extract for 30$60 \mathrm{~min}$ at room temperature before shaking once again. Samples were centrifuged for $5 \mathrm{~min}$ at $5000 \times$ $g$ and the supernatant was subsequently transferred to a test tube. Aliquots $(0.1 \mathrm{ml})$ of each sample were mixed with $5 \mathrm{ml}$ of Bradford reagent and soluble polyvinylpyrollidone (concentration: $3 \mathrm{mg}$ PVP $\mathrm{ml}^{-1}$ reagent). The absorbance was read using a spectrophotometer at $595 \mathrm{~nm}$ after 5 and within $10 \mathrm{~min}$ after addition of the reagent. Blanks (aliquots of $0.1 \mathrm{M} \mathrm{NaOH})$ and standards $(0.1 \mathrm{ml}$ aliquots of bovine serum albumin dissolved in $0.1 \mathrm{M} \mathrm{NaOH}$ ) were treated as the samples. The amount of $\mathrm{N}$ bound in soluble proteins was finally estimated assuming an average $\mathrm{C}: \mathrm{N}$ ratio of $6.1: 1$.

\section{Chlorophyll-bound $\mathrm{N}$}

Chlorophyll $a+b$ concentrations were determined on duplicate leaf samples from each aquarium using the method of Wintermans \& De Mots (1965). Samples were freeze-dried, ground and extracted overnight in $96 \%$ ethanol. The extract was filtered and the chlorophyll concentrations were determined spectrophotometrically at wavelengths of 649,665 and $750 \mathrm{~nm}$. The amount of chlorophyll-bound $\mathrm{N}$ was estimated assuming that $\mathrm{N}$ constituted $6.23 \%$ of the molar weight of chlorophyll a (Stryer 1981).

\section{Residual N}

The amount of $\mathrm{N}$ not accounted for by the aforementioned analyses was termed residual N. This pool was likely made up by a mixture of structural proteins, cyclic amino acids and other low molecular weight $\mathrm{N}$ compounds, and was estimated as the total amount of $\mathrm{N}$ minus the $\mathrm{N}$ bound in intracellular $\mathrm{NH}_{4}{ }^{+}, \mathrm{NO}_{3}{ }^{-}$, chlorophyll, FAA and soluble proteins.

\section{Sucrose and starch}

The concentrations of sucrose and starch were measured on duplicate leaf and rhizome samples from each aquarium. Samples were freeze-dried and ground prior to analysis. Total non-structural carbohydrates were measured following Brun et al. (2002). Sugars (sucrose and hexoses) were first solubilized by 4 sequential extractions in $96 \%$ (v/v) ethanol at $80^{\circ} \mathrm{C}$ for $15 \mathrm{~min}$. The ethanol extracts were evaporated under a stream of air at $40^{\circ} \mathrm{C}$ and the residues were then dissolved in $10 \mathrm{ml}$ of deionized water for analysis. Starch was extracted from the ethanolinsoluble residue by keeping it for $24 \mathrm{~h}$ in $1 \mathrm{~N} \mathrm{NaOH}$. The sucrose and starch content of the extracts was determined spectrophotometrically using a resorcinol and anthrone assay with an absorbance of 486 and $640 \mathrm{~nm}$, respectively, with sucrose as a standard.

\section{Statistical treatment}

We used 2-factorial (for physiological and morphological response variables) or 3-factorial (for biochemical response variables) permutational MANOVA (PERMANOVA) to test for effects of the treatments $\left(\mathrm{NH}_{4}{ }^{+}\right.$enrichment, light level and plant part, i.e. 
leaves and roots/rhizomes) and their interactions. All treatment factors were considered fixed. The multivariate approach was chosen because all response variables were obtained from plants originating from the same experimental unit (aquarium) and because many of the response variables were likely intercorrelated. Data were normalized to minimize scale differences among response variables before analysis and PERMANOVA was executed using Type III sum of squares on geometric (Euclidean) distances and unrestricted permutation of raw data (Anderson et al. 2008).

Univariate permutational ANOVA (2- or 3-factorial) was subsequently used to test the effect of the treatment factors and their interactions on each response variable separately as suggested by Quinn \& Keough (2002). These tests were also conducted using Type III sum of squares on geometric (Euclidean) distances and unrestricted permutation of raw data. All tests (permutational MANOVA and ANOVA) were carried out using an $\alpha$-level of 0.05 .

\section{RESULTS}

\section{Physiological and morphological properties}

The composite response of all physiological and morphological parameters was affected by the interaction between $\mathrm{NH}_{4}{ }^{+}$addition and light (PERMANOVA, $\mathrm{p}=0.007$; Table 1). Enrichment with $\mathrm{NH}_{4}{ }^{+}$ affected the composite response variable negatively at low light, but not at high light.

High $\mathrm{NH}_{4}{ }^{+}$levels affected most of the individual response variables negatively under low-light conditions, whereas no clear or even positive effects of $\mathrm{NH}_{4}{ }^{+}$ were recorded under high-light conditions. Maximum photosynthetic and respiration rates (Fig. 1A) were not affected significantly by $\mathrm{NH}_{4}{ }^{+}$, light or their interaction ( $p>0.05$, Table 1 ), although $P_{\max }$ in plants cultivated in low light tended to decrease with increasing $\mathrm{NH}_{4}{ }^{+}$loading and the opposite trend was recorded in plants cultivated in high light.

Net production (i.e. net changes in plant biomass) was significantly affected by the interaction between $\mathrm{NH}_{4}{ }^{+}$and light (Fig. 1B, Table 1): $\mathrm{NH}_{4}{ }^{+}$enrichment caused a marked reduction in net production at low light, decreasing from ca. $15 \mathrm{mg} \mathrm{FW} \mathrm{shoot}^{-1} \mathrm{~d}^{-1}$ in the control to almost $-10 \mathrm{mg}$ FW shoot ${ }^{-1} \mathrm{~d}^{-1}$ under the highest $\mathrm{NH}_{4}{ }^{+}$loading. $\mathrm{NH}_{4}{ }^{+}$enrichment had, in contrast, no effect on net production under high-light conditions (mean across $\mathrm{N}$ levels was ca. $22 \mathrm{mg}$ FW $\left.\operatorname{shoot}^{-1} d^{-1}\right)$.
Table 1. Statistical results of the MANOVA (composite response) and ANOVA (individual responses) analyses examining the effect of light level and ammonium supply on various morphological and physiological properties of Zostera marina

\begin{tabular}{|lrrrc|}
\hline & df & MS & Pseudo-F & $\mathrm{p}$ \\
\hline Variable, factors & & & & \\
MANOVA & 2 & 11.79 & 2.30 & 0.029 \\
Ammonium supply (N) & 1 & 38.88 & 7.60 & 0.002 \\
Light (L) & 2 & 14.56 & 2.84 & 0.007 \\
L $\times$ N & & & & \\
ANOVA & & & & \\
Photosynthetic rate (P) & & \\
Ammonium supply (N) & 2 & 0.217 & 0.22 & 0.817 \\
Light (L) & 1 & 0.005 & 0.01 & 0.823 \\
L $\times$ N & 2 & 2.235 & 0.23 & 0.139 \\
Respiration rate (R) & & & & \\
Ammonium supply (N) & 2 & 0.560 & 0.51 & 0.604 \\
Light (L) & 1 & 0.051 & 0.05 & 0.832 \\
L $\times$ N & 2 & 1.380 & 1.27 & 0.310 \\
Net production (NP) & & & & \\
Ammonium supply (N) & 2 & 1.363 & 7.20 & 0.008 \\
Light (L) & 1 & 9.077 & 47.90 & 0.001 \\
L $\times$ N & 2 & 1.461 & 7.71 & 0.005 \\
Leaf elongation rate (LER) & & & & \\
Ammonium supply (N) & 2 & 2.77 & 7.04 & 0.010 \\
Light (L) & 1 & 6.69 & 17.01 & 0.001 \\
L $\times$ N & 2 & 0.024 & 0.06 & 0.940 \\
Plastochrone interval (PI) & & & & \\
Ammonium supply (N) & 2 & 0.658 & 2.47 & 0.132 \\
Light (L) & 1 & 11.921 & 44.74 & 0.001 \\
L $\times$ N & 2 & 0.282 & 1.06 & 0.388 \\
Side-shoot appearance rate & & & \\
Ammonium supply (N) & 2 & 0.068 & 0.09 & 0.935 \\
Light (L) & 1 & 0.551 & 0.70 & 0.432 \\
L $\times$ N & 2 & 3.402 & 4.29 & 0.031 \\
Leaf abundance & & & & \\
Ammonium supply (N) & 2 & 2.401 & 15.04 & 0.001 \\
Light (L) & 1 & 6.865 & 43.02 & 0.001 \\
L $\times$ N & 2 & 1.709 & 10.71 & 0.001 \\
Necrosis & & & & \\
Ammonium supply (N) & 2 & 3.285 & 26.71 & 0.001 \\
Light (L) & 2.641 & 21.48 & 0.001 \\
L $\times$ N & & & \\
\hline
\end{tabular}

Leaf elongation rate (Fig. 1C) was affected by both $\mathrm{NH}_{4}{ }^{+}$loading and light, but not by their interaction (Table 1). Leaf elongation decreased from 2.6 to $2.1 \mathrm{~cm}$ shoot ${ }^{-1} \mathrm{~d}^{-1}$ with increasing $\mathrm{NH}_{4}{ }^{+}$concentration at low light, but increased from 2.6 to $3.1 \mathrm{~cm}$ shoot ${ }^{-1} \mathrm{~d}^{-1}$ with increasing $\mathrm{NH}_{4}{ }^{+}$concentration at high light. The plastochrone interval (Fig. 1D) was only affected significantly by light (Table 1), being 25-30\% higher in plants cultivated under low light than in those exposed to high light. The plastochrone interval tended to increase with increasing $\mathrm{NH}_{4}{ }^{+}$ addition in plants held at low light.

The production of side-shoots (Fig. 1E) was affected by the interaction between $\mathrm{NH}_{4}{ }^{+}$and light 

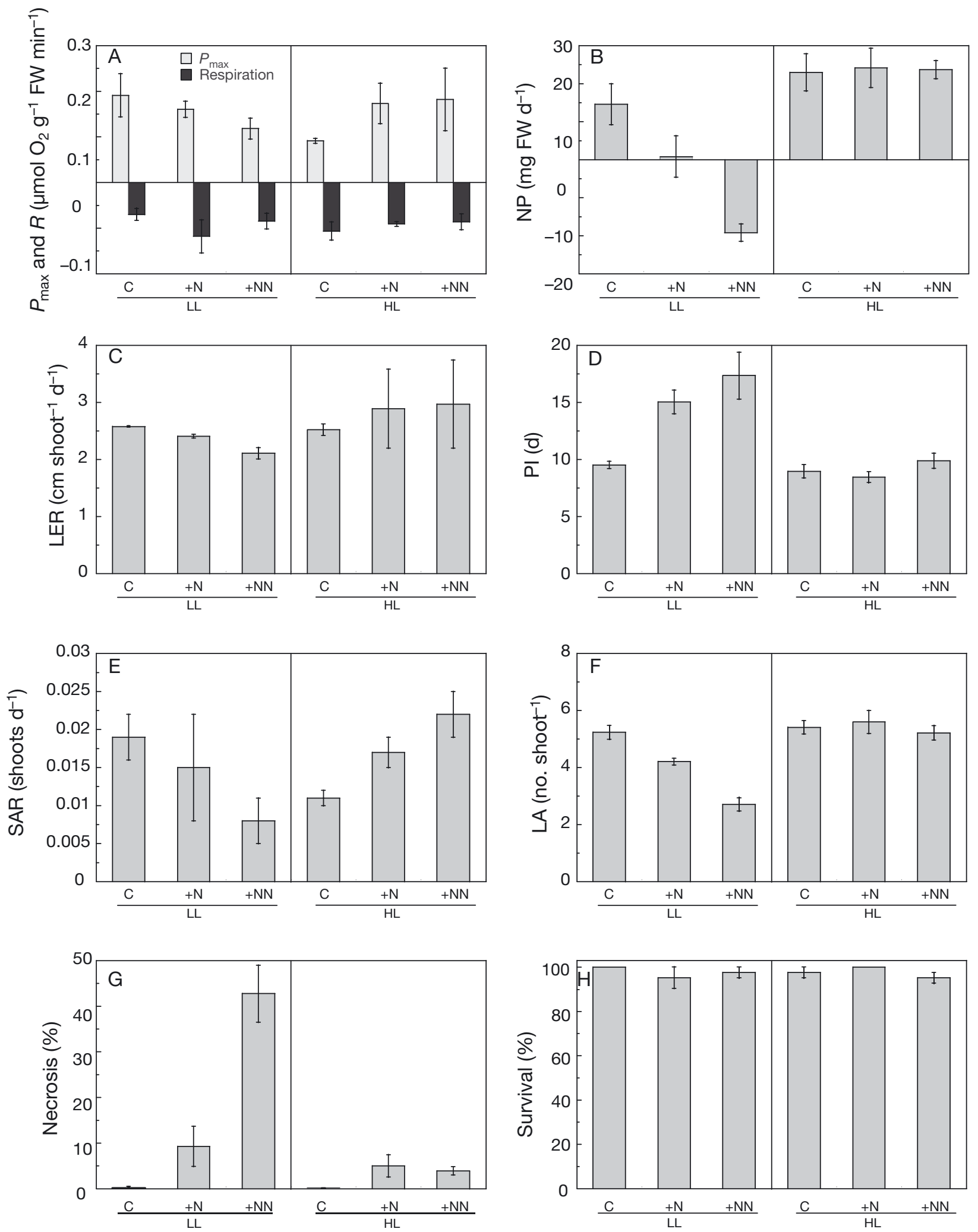

Fig. 1. Zostera marina. Dynamics and physiological features of plants under each ammonium and light treatment (means $\pm \mathrm{SE}$ across 3 replicate aquaria): (A) maximum photosynthetic $\left(P_{\max }\right)$ and respiration rate $(R)$, (B) leaf elongation rate (LER), $(C)$ plastochrone interval (PI), (D) shoot appearance rate (SAR), (E) leaf abundance (LA), (F) net production (NP), (G) degree of necrosis, and $(\mathrm{H})$ survival rate (SR). $\mathrm{C}_{1}+\mathrm{N},+\mathrm{NN}$ : 0, 10, $25 \mu \mathrm{M}$ ammonium concentration, respectively; LL: low light; HL: high light 
(Table 1). New side-shoots were produced at a rate of 0.018 shoot $^{-1} \mathrm{~d}^{-1}$ without $\mathrm{NH}_{4}^{+}$enrichment in low light, but this rate was reduced to 0.007 shoot $^{-1} \mathrm{~d}^{-1}$ in the high $\mathrm{NH}_{4}{ }^{+}$treatment. In contrast, enrichment with $\mathrm{NH}_{4}{ }^{+}$stimulated the production of new shoots (from 0.012 to 0.022 shoot $^{-1} \mathrm{~d}^{-1}$ ) in high light. Leaf abundance (Fig. 1F) was significantly affected by the interaction between $\mathrm{NH}_{4}{ }^{+}$and light (Table 1): the number of leaves per shoot was reduced from 5.2 in the control to ca. 2.5 at high $\mathrm{NH}_{4}{ }^{+}$addition in low light.

The degree of necrosis (Fig. 1G) was affected by the interaction between $\mathrm{NH}_{4}{ }^{+}$and light (Table 1). In low light, necrosis increased from ca. $0 \%$ in the control treatment to more than $40 \%$ in the $+\mathrm{NN}$ treatment. A similar pattern occurred under high light, although at much lower levels (max. ca. 5\%). Survival (Fig. 1H) was unaffected by all treatment factors and remained close to $100 \%$ in all the treatment combinations.

\section{$\mathbf{N}$ pools}

The composite response of all N-related response parameters was affected by light and by the $\mathrm{NH}_{4}{ }^{+} \times$ tissue interaction (PERMANOVA, $\mathrm{p}=0.002$ and $\mathrm{p}=$ 0.006 , respectively; Table 2). The effect of $\mathrm{NH}_{4}^{+}$ enrichment was stronger in leaves (all 3 treatment levels different from each other, $\mathrm{p}<0.05$ ) than in the roots/rhizomes ( $\mathrm{C}$ treatment only different from the $+\mathrm{NN}$ treatment, $\mathrm{p}=0.007$ ). Total $\mathrm{N}$ and most of the $\mathrm{N}$ species within the plants (i.e. intracellular inorganic $\mathrm{N}$, FAA and residual $\mathrm{N}$ ) increased substantially with $\mathrm{NH}_{4}{ }^{+}$enrichment, although the content of soluble proteins showed the opposite pattern. All N species were typically more abundant in plants grown under low light than under high light, and levels were also higher in leaves than in the roots/rhizomes.

Total N (Fig. 2A) was significantly affected by plant part and the interaction between $\mathrm{NH}_{4}{ }^{+}$and light (Table 2). Total N was 2-fold higher in leaves than in the roots/rhizomes, and increased about 30-50\% with $\mathrm{NH}_{4}{ }^{+}$addition, being ca. $2.5 \%$ of DW in the $+\mathrm{NN}$ treatment. The relative increase in total $\mathrm{N}$ with $\mathrm{NH}_{4}{ }^{+}$ enrichment was larger in plants cultivated under high light than under low light.

Intracellular $\mathrm{NH}_{4}^{+}$(Fig. 2B) constituted less than $1 \%$ of total $\mathrm{N}$, but was affected significantly by $\mathrm{NH}_{4}{ }^{+}$ enrichment, light and plant part, but not by any of the interactions (Table 2). Intracellular $\mathrm{NH}_{4}{ }^{+}$increased substantially with $\mathrm{NH}_{4}{ }^{+}$enrichment and levels were
Table 2. Statistical results of the MANOVA (composite response) and ANOVA (individual responses) analyses examining the effect of light level, ammonium supply and plant tissue on various $\mathrm{N}$ pools (total $\mathrm{N}$, ammonium- $\mathrm{N}$, nitrate- $\mathrm{N}$, free amino acid-N, soluble protein-N, chlorophyllbound $\mathrm{N}$ and residual $\mathrm{N}$ ) in Zostera marina

\begin{tabular}{|c|c|c|c|c|}
\hline Variable, factors & df & MS & Pseudo- $F$ & $\mathrm{p}$ \\
\hline \multicolumn{5}{|l|}{ MANOVA } \\
\hline Ammonium supply (N) & 2 & 27.431 & 11.63 & 0.001 \\
\hline Light (L) & 1 & 18.181 & 7.71 & 0.002 \\
\hline Tissue (Ti) & 1 & 86.517 & 36.69 & 0.001 \\
\hline $\mathrm{N} \times \mathrm{L}$ & 2 & 1.961 & 0.83 & 0.509 \\
\hline $\mathrm{N} \times \mathrm{Ti}$ & 2 & 8.809 & 3.74 & 0.006 \\
\hline $\mathrm{L} \times \mathrm{Ti}$ & 1 & 1.933 & 0.82 & 0.441 \\
\hline $\mathrm{N} \times \mathrm{L} \times \mathrm{Ti}$ & 2 & 5.367 & 1.14 & 0.319 \\
\hline \multicolumn{5}{|l|}{ ANOVA } \\
\hline \multicolumn{5}{|l|}{ Total $\mathbf{N}$ content } \\
\hline Ammonium supply (N) & 2 & 4.946 & 66.10 & 0.001 \\
\hline Light (L) & 1 & 1.315 & 17.58 & 0.001 \\
\hline Tissue (Ti) & 1 & 19.450 & 259.96 & 0.001 \\
\hline $\mathrm{N} \times \mathrm{L}$ & 2 & 0.263 & 3.51 & 0.049 \\
\hline $\mathrm{N} \times \mathrm{Ti}$ & 2 & 0.572 & 7.65 & 0.003 \\
\hline $\mathrm{L} \times \mathrm{Ti}$ & 1 & 0.084 & 1.13 & 0.311 \\
\hline $\mathrm{N} \times \mathrm{L} \times \mathrm{Ti}$ & 2 & 0.397 & 5.31 & 0.018 \\
\hline \multicolumn{5}{|l|}{ Ammonium content } \\
\hline Ammonium supply (N) & 2 & 4.563 & 9.11 & 0.003 \\
\hline Light (L) & 1 & 2.992 & 5.98 & 0.026 \\
\hline Tissue (Ti) & 1 & 8.279 & 16.53 & 0.001 \\
\hline $\mathrm{N} \times \mathrm{L}$ & 2 & 0.053 & 0.11 & 0.888 \\
\hline $\mathrm{N} \times \mathrm{Ti}$ & 2 & 1.081 & 2.16 & 0.138 \\
\hline $\mathrm{L} \times \mathrm{Ti}$ & 1 & 0.287 & 0.57 & 0.471 \\
\hline $\mathrm{L} \times \mathrm{N} \times \mathrm{Ti}$ & 2 & 0.016 & 0.03 & 0.969 \\
\hline \multicolumn{5}{|l|}{ Nitrate content } \\
\hline Ammonium supply (N) & 2 & 1.032 & 1.00 & 0.375 \\
\hline Light (L) & 1 & 4.559 & 4.42 & 0.059 \\
\hline Tissue (Ti) & 1 & 1.140 & 1.10 & 0.329 \\
\hline $\mathrm{N} \times \mathrm{L}$ & 2 & 0.107 & 0.10 & 0.895 \\
\hline $\mathrm{N} \times \mathrm{Ti}$ & 2 & 0.090 & 0.09 & 0.925 \\
\hline $\mathrm{L} \times \mathrm{Ti}$ & 1 & 0.099 & 0.10 & 0.755 \\
\hline $\mathrm{L} \times \mathrm{N} \times \mathrm{Ti}$ & 2 & 0.983 & 0.95 & 0.424 \\
\hline \multicolumn{5}{|l|}{ Free amino acids } \\
\hline Ammonium supply (N) & 2 & 6.834 & 49.78 & 0.001 \\
\hline Light (L) & 1 & 0.830 & 6.05 & 0.024 \\
\hline Tissue (Ti) & 1 & 8.789 & 64.02 & 0.001 \\
\hline $\mathrm{N} \times \mathrm{L}$ & 2 & 0.684 & 4.98 & 0.017 \\
\hline $\mathrm{N} \times \mathrm{T}$ & 2 & 3.034 & 22.10 & 0.001 \\
\hline $\mathrm{L} \times \mathrm{Ti}$ & 1 & 0.367 & 2.68 & 0.107 \\
\hline $\mathrm{L} \times \mathrm{N} \times \mathrm{Ti}$ & 2 & 0.307 & 2.24 & 0.141 \\
\hline \multicolumn{5}{|l|}{ Soluble proteins } \\
\hline Ammonium supply (N) & 2 & 3.238 & 8.39 & 0.002 \\
\hline Light (L) & 1 & 4.448 & 11.52 & 0.002 \\
\hline Tissue (Ti) & 1 & 8.315 & 21.54 & 0.001 \\
\hline $\mathrm{N} \times \mathrm{L}$ & 2 & 0.045 & 0.12 & 0.883 \\
\hline $\mathrm{N} \times \mathrm{T}$ & 2 & 2.792 & 7.24 & 0.006 \\
\hline $\mathrm{L} \times \mathrm{Ti}$ & 1 & 0.276 & 0.72 & 0.362 \\
\hline $\mathrm{L} \times \mathrm{N} \times \mathrm{Ti}$ & 2 & 0.274 & 0.71 & 0.502 \\
\hline \multicolumn{5}{|l|}{ Chorophyll $a+b$} \\
\hline Ammonium supply (N) & 2 & 0.434 & 2.41 & 0.132 \\
\hline Light (L) & 1 & 1.416 & 7.85 & 0.009 \\
\hline $\mathrm{N} \times \mathrm{L}$ & 2 & 0.277 & 1.54 & 0.250 \\
\hline \multicolumn{5}{|l|}{ Residual N } \\
\hline Ammonium supply (N) & 2 & 6.601 & 48.14 & 0.001 \\
\hline Light (L) & 1 & 3.329 & 24.28 & 0.001 \\
\hline Tissue (Ti) & 1 & 10.545 & 76.91 & 0.001 \\
\hline $\mathrm{N} \times \mathrm{L}$ & 2 & 0.669 & 4.88 & 0.012 \\
\hline $\mathrm{N} \times \mathrm{T}$ & 2 & 1.024 & 7.47 & 0.003 \\
\hline $\mathrm{L} \times \mathrm{Ti}$ & 1 & 0.112 & 0.82 & 0.391 \\
\hline $\mathrm{L} \times \mathrm{N} \times \mathrm{Ti}$ & 2 & 0.568 & 4.14 & 0.024 \\
\hline
\end{tabular}



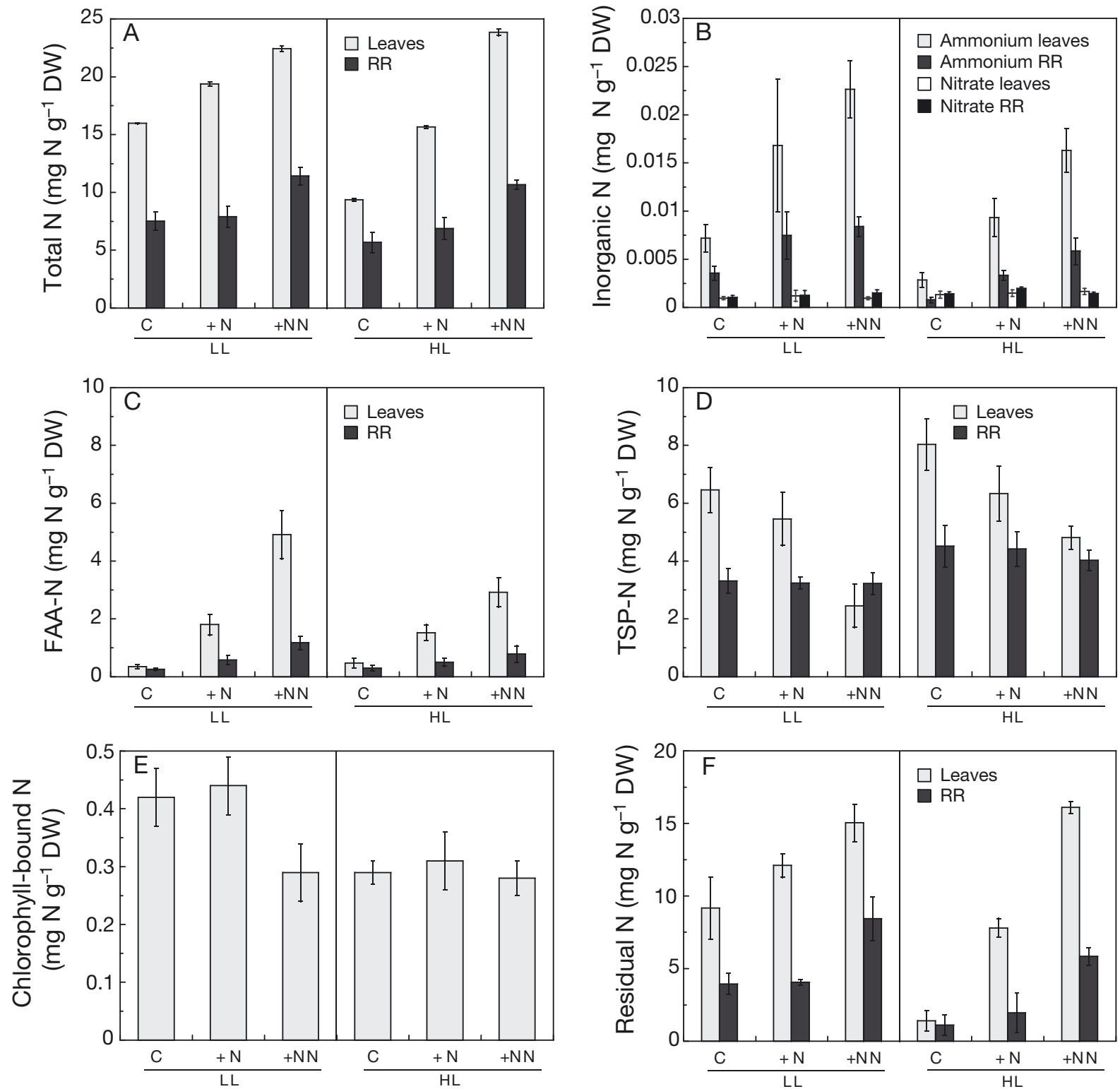

Fig. 2. Zostera marina. Nitrogen pools in aboveground (leaves) and belowground (root/rhizomes, RR) tissues under each ammonium and light treatments (means \pm SE across 3 replicate aquaria): (A) total nitrogen content, (B) intracellular nitrogen content (ammonium and nitrate), (C) free amino acid nitrogen (FAA-N), (D) total soluble protein nitrogen (TSP-N), (E) chlorophyll-bound

$\mathrm{N}$, and (F) residual nitrogen. $\mathrm{C},+\mathrm{N},+\mathrm{NN}$ : 0, 10, $25 \mu \mathrm{M}$ ammonium concentration, respectively; LL: low light; HL: high light

higher in plants grown in low light than in high light. Leaves contained always more $\mathrm{NH}_{4}{ }^{+}$than the roots/ rhizomes.

Intracellular $\mathrm{NO}_{3}{ }^{-}$made up less than $1 \%$ of total $\mathrm{N}$ (Fig. 2B) and was only affected by light ( $\mathrm{p}=0.046)$; levels were higher in plants cultivated under high light.

Nitrogen bound in free amino acids (FAA-N) made up between 4 and $12 \%$ of total $\mathrm{N}$ depending on treatment (Fig. 2C). FAA-N was affected by the interactions between $\mathrm{NH}_{4}{ }^{+}$and light and $\mathrm{NH}_{4}{ }^{+}$and plant part (Table 2). FAA-N increased more with $\mathrm{NH}_{4}{ }^{+}$ enrichment in the leaves than in the roots/rhizomes and more in low light than in high light.

The amount of $\mathrm{N}$ bound in soluble proteins (TSP-N) made up 25-60\% of total N (Fig. 2D) and was affected significantly by light and by the interaction between $\mathrm{NH}_{4}{ }^{+}$and plant part (Table 2), but responded quite different than the other $\mathrm{N}$ species. TSP-N in leaves decreased markedly with $\mathrm{NH}_{4}{ }^{+}$enrichment, being $30-60 \%$ lower in plants from the $+\mathrm{NN}$ treatment than in those from the control treatment. TSP-N in the roots/rhizomes was relatively unaffected by 

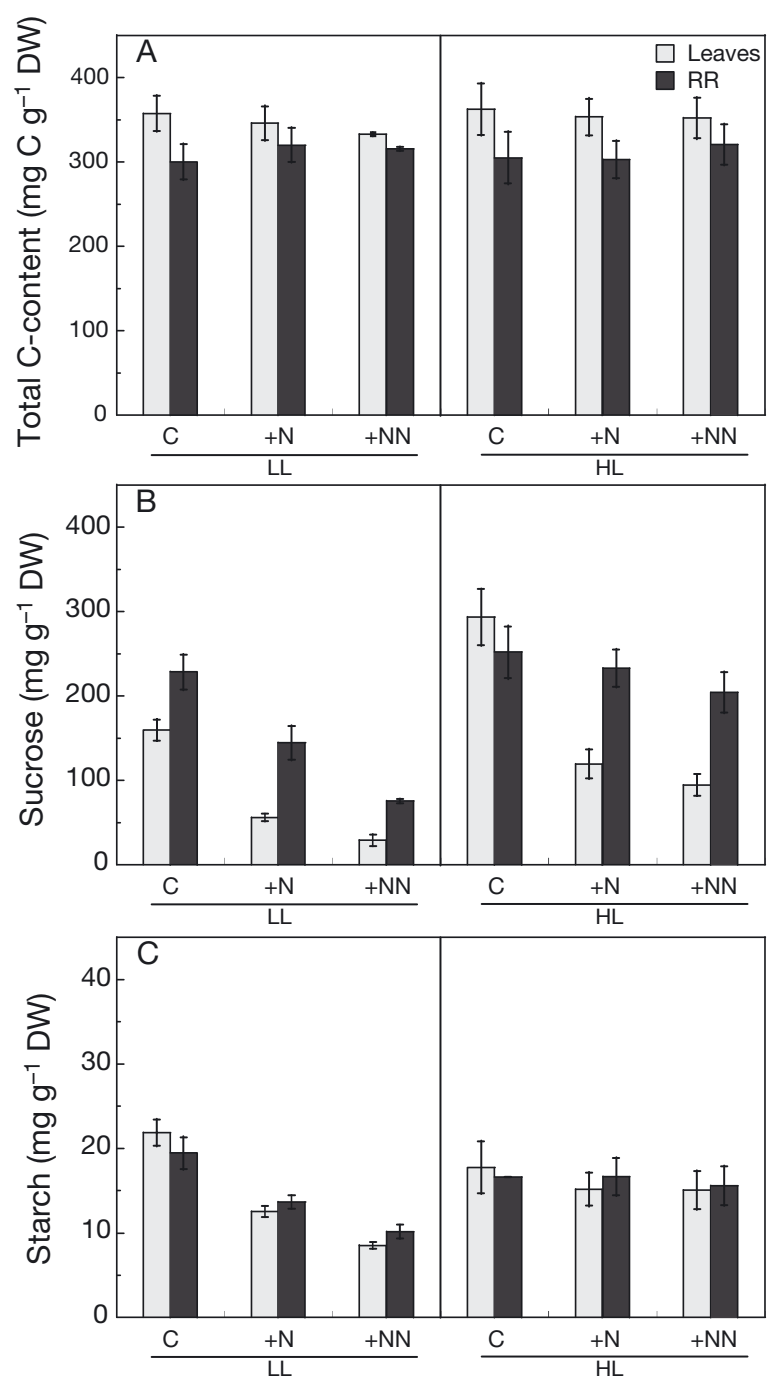

Fig. 3. Zostera marina. (A) Carbon content, (B) sucrose and (C) starch concentration in aboveground (leaves) and belowground (roots/rhizomes, RR) tissues under low light (LL) or high light (HL) and different ammonium supply $\left(\mathrm{C}_{1}+\mathrm{N}\right.$, $+\mathrm{NN}$ : $0,10,25 \mu \mathrm{M}$, respectively) as treatments. Data are means \pm SE across 3 replicate aquaria

$\mathrm{NH}_{4}{ }^{+}$treatment. TSP-N was higher in plants grown in high than in low light.

The amount of $\mathrm{N}$ bound in chlorophyll $a+b$ (Chl-N) made up $1-2 \%$ of total $\mathrm{N}$ in the leaves (Fig. 2E). Chl-N was only affected by the light (Table 2), being ca. $30 \%$ higher in plants grown in low light than in high light.

The amount of residual $\mathrm{N}$ compounds made up $30-63 \%$ of total $\mathrm{N}$ depending on treatment and plant part (Fig. 2F). Residual $\mathrm{N}$ was affected by the highest order interaction (i.e. $\mathrm{NH}_{4}{ }^{+} \times$light $\times$plant part); the amount increased with $\mathrm{NH}_{4}{ }^{+}$enrichment, but more so in the roots/rhizomes than in the leaves and more so in high light than in low light.
Table 3. Statistical results of the MANOVA (composite response) and ANOVA (individual responses) analyses examining the effect of light level, ammonium supply and plant tissue on various carbon pools (total carbon, sucrose and starch) in Zostera marina

\begin{tabular}{|c|c|c|c|c|}
\hline Variable, factors & $\mathrm{df}$ & MS & $F$ & $\mathrm{p}$ \\
\hline \multicolumn{5}{|l|}{ MANOVA } \\
\hline Ammonium supply (N) & 2 & 11.922 & 8.75 & 0.001 \\
\hline Light (L) & 1 & 9.551 & 7.01 & 0.001 \\
\hline Tissue (Ti) & 1 & 26.527 & 19.46 & 0.001 \\
\hline $\mathrm{N} \times \mathrm{L}$ & 2 & 2.901 & 2.13 & 0.079 \\
\hline $\mathrm{N} \times \mathrm{T}$ & 2 & 2.045 & 1.52 & 0.203 \\
\hline $\mathrm{L} \times \mathrm{Ti}$ & 1 & 0.415 & 0.30 & 0.790 \\
\hline $\mathrm{L} \times \mathrm{N} \times \mathrm{Ti}$ & 2 & 0.996 & 0.73 & 0.615 \\
\hline \multicolumn{5}{|l|}{ ANOVA } \\
\hline \multicolumn{5}{|l|}{ Total carbon } \\
\hline Ammonium supply (N) & 2 & 0.030 & 0.08 & 0.916 \\
\hline Light (L) & 1 & 0.320 & 0.83 & 0.370 \\
\hline Tissue (Ti) & 1 & 21.725 & 56.21 & 0.001 \\
\hline $\mathrm{N} \times \mathrm{L}$ & 2 & 0.438 & 1.13 & 0.349 \\
\hline $\mathrm{N} \times \mathrm{T}$ & 2 & 1.013 & 2.62 & 0.090 \\
\hline $\mathrm{L} \times \mathrm{Ti}$ & 1 & 0.387 & 1.00 & 0.308 \\
\hline $\mathrm{L} \times \mathrm{N} \times \mathrm{Ti}$ & 2 & 0.165 & 0.43 & 0.655 \\
\hline \multicolumn{5}{|l|}{ Sucrose } \\
\hline Ammonium supply (N) & 2 & 7.231 & 41.18 & 0.001 \\
\hline Light (L) & 1 & 8.274 & 47.12 & 0.001 \\
\hline Tissue (Ti) & 1 & 4.796 & 27.31 & 0.001 \\
\hline $\mathrm{N} \times \mathrm{L}$ & 2 & 0.060 & 0.34 & 0.736 \\
\hline $\mathrm{N} \times \mathrm{T}$ & 2 & 0.783 & 4.46 & 0.014 \\
\hline $\mathrm{L} \times \mathrm{Ti}$ & 1 & 0.020 & 0.11 & 0.721 \\
\hline $\mathrm{L} \times \mathrm{N} \times \mathrm{Ti}$ & 2 & 0.774 & 4.41 & 0.026 \\
\hline \multicolumn{5}{|l|}{ Starch } \\
\hline Ammonium supply (N) & 2 & 4.661 & 5.82 & 0.007 \\
\hline Light (L) & 1 & 0.957 & 1.19 & 0.304 \\
\hline Tissue (Ti) & 1 & 0.007 & 0.01 & 0.939 \\
\hline $\mathrm{N} \times \mathrm{L}$ & 2 & 2.403 & 3.00 & 0.073 \\
\hline $\mathrm{N} \times \mathrm{T}$ & 2 & 0.279 & 0.35 & 0.719 \\
\hline $\mathrm{L} \times \mathrm{Ti}$ & 1 & 0.008 & 0.01 & 0.916 \\
\hline $\mathrm{L} \times \mathrm{N} \times \mathrm{Ti}$ & 2 & 0.057 & 0.07 & 0.920 \\
\hline
\end{tabular}

\section{C pools}

The composite response of all C-related response parameters was affected by all main factors, i.e. $\mathrm{N}$ treatment, light and plant part (all $\mathrm{p}<0.001$; Table 3), but not by any of the interactions. Total $\mathrm{C}$ content (Fig. 3A) averaged $350.6 \pm 10.4$ and $309.7 \pm$ $8.8 \mathrm{mg} \mathrm{C} \mathrm{g}^{-1} \mathrm{DW}$ in leaves and roots/rhizomes, respectively, and was only affected significantly by plant part (Table 3).

The concentration of sucrose (Fig. 3B) was affected by the highest order $\left(\mathrm{NH}_{4}{ }^{+} \times\right.$light $\times$plant part $)$interaction (Table 3). Sucrose decreased substantially with $\mathrm{NH}_{4}{ }^{+}$enrichment and the decrease was largest in low-light plants where the content in leaves de- 
Table 4. Zostera marina. C:N, sucrose-C:total $\mathrm{C}$ and sucrose-C:FAA-N ratios under each ammonium and light treatment in aboveground (leaves) and belowground (roots/rhizomes, RR) tissues (mean $\pm \mathrm{SE}$ ). $\mathrm{C},+\mathrm{N},+\mathrm{NN}$ : 0, 10, $25 \mu \mathrm{M}$, respectively; LL: low light; HL: high light

\begin{tabular}{|c|c|c|c|c|c|c|c|}
\hline \multicolumn{2}{|c|}{ — Treatment — } & \multicolumn{2}{|c|}{ C:N (molar ratio) } & \multicolumn{2}{|c|}{ Sucrose-C:Total C (\%) } & \multicolumn{2}{|c|}{ Sucrose-C:FAA-N (mg C mg $\left.{ }^{-1} \mathrm{~N}\right)$} \\
\hline Light & $\mathrm{NH}_{4}^{+}$ & Leaves & $\mathrm{RR}$ & Leaves & RR & Leaves & $\mathrm{RR}$ \\
\hline \multirow[t]{3}{*}{ LL } & $\mathrm{C}$ & $26.6 \pm 2.7$ & $46.6 \pm 1.0$ & $18.8 \pm 1.4$ & $32.0 \pm 1.5$ & $202.0 \pm 37$ & $370.3 \pm 37.9$ \\
\hline & $+\mathrm{N}$ & $20.8 \pm 0.3$ & $47.3 \pm 1.1$ & $6.8 \pm 0.7$ & $18.9 \pm 0.9$ & $14.0 \pm 2.6$ & $122.8 \pm 37.3$ \\
\hline & $+\mathrm{NN}$ & $17.4 \pm 1.0$ & $28.6 \pm 3.9$ & $3.7 \pm 0.8$ & $10.8 \pm 0.6$ & $2.9 \pm 1.1$ & $29.2 \pm 2.9$ \\
\hline \multirow[t]{3}{*}{ HL } & $\mathrm{C}$ & $45.4 \pm 2.4$ & $62.6 \pm 2.7$ & $34.0 \pm 3.4$ & $33.1 \pm 5.5$ & $282.7 \pm 68.1$ & $448.6 \pm 229.9$ \\
\hline & $+\mathrm{N}$ & $26.4 \pm 1.3$ & $52.1 \pm 3.1$ & $14.2 \pm 2.0$ & $29.6 \pm 1.8$ & $34.2 \pm 7.1$ & $205.3 \pm 59.7$ \\
\hline & $+\mathrm{NN}$ & $17.3 \pm 0.6$ & $36.0 \pm 4.0$ & $11.4 \pm 1.7$ & $27.3 \pm 4.1$ & $13.6 \pm 0.3$ & $135.5 \pm 37.3$ \\
\hline
\end{tabular}

creased to ca. $16 \%$ of that in plants from the control treatment. The decrease in sucrose content with $\mathrm{NH}_{4}{ }^{+}$enrichment was more pronounced in leaves than in the roots/rhizomes.

The starch content was always one order of magnitude lower than that of sucrose (Fig. 3C). Starch was only affected significantly by $\mathrm{NH}_{4}{ }^{+}$treatment (Table 3). The content of starch was rather similar in leaves and roots/rhizomes and $\mathrm{NH}_{4}{ }^{+}$enrichment caused a significant drop in starch in both plant parts. Plants cultivated under high light had similar contents of starch across $\mathrm{NH}_{4}{ }^{+}$treatments.

Ratios of C:N, sucrose-C:total C and sucrose-C: FAA-N were typically higher in the root/rhizomes than in leaves (Table 4). The $\mathrm{C}: \mathrm{N}$ ratio mainly reflected variations in total $\mathrm{N}$ and declined with $\mathrm{NH}_{4}{ }^{+}$enrichment. The sucrose-C:total $\mathrm{C}$ ratio mainly reflected changes in the sucrose content and was strongly influenced by $\mathrm{NH}_{4}{ }^{+}$enrichment and light, reaching its lowest values in the $+\mathrm{NN}$ treatment under low light. The sucrose-C:FAA-N ratio was affected by $\mathrm{NH}_{4}{ }^{+}$enrichment and light, being lowest at high $\mathrm{NH}_{4}{ }^{+}$-enrichment combined with low light.

\section{DISCUSSION}

Our study demonstrated that relatively high, but ecologically relevant, concentrations of $\mathrm{NH}_{4}^{+}$(i.e. in the range of $0-10$ and $0-25 \mu \mathrm{M})$ in the water had significant negative effects on the composite and on several individual physiological responses that represented plant fitness. Exposure to 10 and $25 \mu \mathrm{M}$ $\mathrm{NH}_{4}{ }^{+}$for $5 \mathrm{wk}$ lead to leaf necrosis, and slowed down the leaf growth rate, the production of side-shoots, the leaf abundance and the net growth rate, but did not affect photosynthesis, respiration, plastochrone interval or survival. The adverse effects of $\mathrm{NH}_{4}^{+}$ were intensified when plants were cultured under relatively low light.
Toxic effects of high $\mathrm{NH}_{4}{ }^{+}$concentrations are well studied among terrestrial plants, including crop plants (Britto \& Kronzucker 2002). High water concentrations of $\mathrm{NH}_{4}{ }^{+}$can stimulate leaf necrosis and reduce the photosynthetic performance, leaf elongation rate, shoot size, biomass and survival in several seagrass species (e.g. van Katwijk et al. 1997, Brun et al. 2002, 2008, van der Heide et al. 2008). The negative responses reported in these studies show a great deal of variability depending on the experimental set-up (i.e. applied $\mathrm{N}$ concentrations, pulsed versus constant enrichment, duration) and seagrass species involved. Most of these studies have, however, exposed plants to rather high concentrations of inorganic N, e.g. 100$200 \mu \mathrm{M} \mathrm{NH}_{4}{ }^{+}$(van Katwijk et al. 1997, Brun et al. 2002, van der Heide et al. 2008, Christianen et al. 2011). Dissolved inorganic N concentrations undergo considerable seasonal variations in eutrophic estuaries, but rarely exceed 100-150 $\mu \mathrm{M}$. A review on nutrient concentrations in 33 Danish estuaries (all considered eutrophic) revealed that the average (across estuaries) concentration of inorganic $\mathrm{N}$ ranges from ca. $100 \mu \mathrm{M}$ in winter (October to March) to a few $\mu \mathrm{M}$ in summer and that the bulk of this nitrogen is in the form of $\mathrm{NO}_{3}{ }^{-}$, whereas $\mathrm{NH}_{4}{ }^{+}$typically makes up less than $10-20 \%$ of the total inorganic N (Conley et al. 2000). Only 2 studies have so far investigated the effect of lower and more ecologically relevant $\mathrm{NH}_{4}{ }^{+}$ concentrations. Brun et al. (2002) found that leaf-elongation, plastochrone interval and net plant growth in Zostera noltii were affected negatively when exposed to a constant concentration of $16 \mathrm{\mu M} \mathrm{NH}_{4}{ }^{+}$, while Brun et al. (2008) reported that ca. $15 \mathrm{\mu M} \mathrm{NH}_{4}{ }^{+}$had a negative effect on net shoot growth and photosynthetic performance $\left(F_{\mathrm{v}} / F_{\mathrm{m}}\right)$ in $Z$. noltii. Brun et al. (2008) further documented that the adverse effect of elevated $\mathrm{NH}_{4}{ }^{+}$was correlated to a reduction in sucrose within the plants and that the negative effects of $\mathrm{NH}_{4}{ }^{+}$were alleviated by high light. These results indicate that the adverse effect of $\mathrm{NH}_{4}{ }^{+}$may be related to increased 
competition for $\mathrm{C}$ skeletons between $\mathrm{NH}_{4}{ }^{+}$assimilation and other metabolic processes (Brun et al. 2008). Uptake of $\mathrm{NH}_{4}^{+}$by seagrasses depends on the external concentration in the medium (Thursby \& Harlin 1982, Rubio et al. 2007, Villazán et al. 2013) and may be passive at high concentrations where low-affinity systems tend to operate (Britto \& Kronzucker 2002). In order to avoid intracellular accumulation of toxic levels of ammonium, this compound is quickly assimilated into amino acids, which are used for the synthesis of proteins or stored if the assimilation of inorganic $\mathrm{N}$ exceeds the requirements needed for growth (e.g. Marschener 1995).

Five weeks of $\mathrm{NH}_{4}{ }^{+}$enrichment led to a doubling of total $\mathrm{N}$ in the plants. All investigated $\mathrm{N}$ pools (with the exception of $\mathrm{NO}_{3}{ }^{-}$and soluble proteins) increased in response to $\mathrm{NH}_{4}{ }^{+}$enrichment. Intracellular $\mathrm{NH}_{4}{ }^{+}$ increased almost 4 -fold, but made up less than $1 \%$ of total $\mathrm{N}$ in all treatments, suggesting rapid assimilation or an active efflux of $\mathrm{NH}_{4}{ }^{+}$(Britto \& Kronzucker 2002). Rapid assimilation seems most feasible since the amount of FAA increased almost 7 -fold in the $+\mathrm{NN}$ treatment relative to that in the control treatment. The amount of $\mathrm{N}$ bound in the residual $\mathrm{N}$ pool, i.e. aromatic and structural amino acids, structural proteins and other $\mathrm{N}$ compounds not accounted for in the chemical analyses, increased by a factor of 3 . The pools of FAA-N and residual $\mathrm{N}$ were both rather large, making up $12.5 \%$ and $62.5 \%$ of total $\mathrm{N}$ in the $+\mathrm{NN}$ treatment, respectively. The large size and substantial increase of these N-pools during N-enrichment indicate that these $\mathrm{N}$-compounds constitute the major storage compounds in eelgrass. Rapid assimilation and synthesis of amino acids and other N compounds were able to keep intracellular concentrations of $\mathrm{NH}_{4}{ }^{+}$low in our plants despite a relatively high external concentration in the medium.

Soluble proteins decreased by almost $50 \%$ with increasing $\mathrm{N}$ enrichment, which was somewhat unexpected given the increase in total FAA and total N. Similar patterns have been observed in terrestrial plants exposed to high $\mathrm{NH}_{4}{ }^{+}$concentrations and it has been suggested that high $\mathrm{NH}_{4}{ }^{+}$availability either causes a higher turnover rate of proteins, or that energy and $\mathrm{C}$ skeletons are diverted from protein synthesis to $\mathrm{NH}_{4}^{+}$assimilation (e.g. DominguezValdivia et al. 2008). This would explain why the concentration of soluble proteins was inversely related to the concentration of FAA. It would also explain why concentrations of soluble proteins were higher while concentrations of FAA were lower in high-light plants where more $\mathrm{C}$ and energy derived from photosynthesis were available.
Sustained synthesis and storage of amino acids may constitute a problem for seagrasses under lowlight conditions since these processes require $C$ skeletons and energy, both of which must be provided from photosynthesis or through mobilization of $C$ reserves. Amino acids have $\mathrm{C}: \mathrm{N}$ ratios ranging from $6: 1$ to $5: 3$, which means that 6 to $1.7 \mathrm{~mol} C$ are required for each mol $\mathrm{N}$ assimilated. Extended periods with high DIN availability and low light may therefore lead to competition between $\mathrm{N}$ assimilation and other metabolic processes for $\mathrm{C}$ and energy.

Ammonium enrichment caused the concentration of sucrose in the leaves to drop 68 and $84 \%$ (in high and low light, respectively) over the course of the experiment, whereas the concentrations in the roots/ rhizomes decreased by 19 and $67 \%$. The starch concentration in the leaves was also reduced, although less than sucrose (15 and 61\% for high- and low-light plants, respectively). Because enrichment with $\mathrm{NH}_{4}{ }^{+}$ did not affect net photosynthesis and respiration significantly, the drop in sucrose and starch cannot be explained by a lower net gain of inorganic $\mathrm{C}$ in plants enriched with $\mathrm{NH}_{4}{ }^{+}$. We suggest that the depletion in sucrose and starch resulted from mobilization of $\mathrm{C}$ reserves to cover the demands related to enhanced assimilation of $\mathrm{NH}_{4}{ }^{+}$. A simple mass balance shows that this is indeed possible. The net uptake of $\mathrm{NH}_{4}{ }^{+}-$ $\mathrm{N}$ over $35 \mathrm{~d}$ in the $+\mathrm{N}$ and high-light treatment amounted to ca. $250 \mu \mathrm{mol} \mathrm{N}$ plant $^{-1}$ (taking growth and changes in total $\mathrm{N}$ into account). If all that $\mathrm{NH}_{4}{ }^{+}-\mathrm{N}$ was assimilated it would correspond to a $\mathrm{C}$ requirement of ca. $625 \mu \mathrm{mol} \mathrm{C}$ plant $^{-1}$ assuming that glutamine (having a $\mathrm{C}: \mathrm{N}$ ratio of 5:2) was the major amino acid being synthesized. Using the observed rates for photosynthesis and respiration (Fig. 1A), net photosynthesis should yield ca. $622 \mu \mathrm{mol} \mathrm{C}$ plant $^{-1}$ over $35 \mathrm{~d}$ (using a $16 \mathrm{~h}$ light:8 h dark cycle), while mobilization of the sucrose and starch could provide $112 \mu \mathrm{mol} \mathrm{C}$ plant $^{-1}$. Photosynthesis and mobilization of $\mathrm{C}$ could thus cover the $\mathrm{C}$ demand needed for assimilation of the acquired N. A similar estimate for plants in the $+\mathrm{NN}$, high-light treatment shows that photosynthesis and mobilization together could provide ca. 1070 of the $1088 \mu \mathrm{mol} \mathrm{C}$ plant $^{-1}$ needed for assimilation of the acquired $\mathrm{N}$.

We were unable to carry out the same sort of estimate for plants grown under low light and $\mathrm{N}$ enrichment due to the large amount of biomass lost by these plants over the course of the experiment. However, these plants were exposed to a light level close to their compensation irradiance and nearly all the $\mathrm{C}$ needed for $\mathrm{N}$ assimilation must therefore have been provided from mobilization of sucrose 
and starch. A larger importance of sucrose and starch mobilization in low-light plants is indicated from the larger drop in both these compounds compared with the high-light plants. Thus, all the metabolic and catabolic processes in plants grown under low light and elevated $\mathrm{NH}_{4}{ }^{+}$concentrations may have undergone tougher competition for $\mathrm{C}$ skeletons and energy, which may have affected growth and fitness of the plants. This hypothesis is supported by studies where addition of $\alpha$-ketoglutarate (i.e. C skeletons) to $\mathrm{N}$-enriched plants can stimulate $\mathrm{N}$ assimilation and the synthesis of amino acids (e.g. Magalhaes et al. 1992).

We found that that high, but ecologically relevant, concentrations of $\mathrm{NH}_{4}{ }^{+}$can have an adverse effect on Zostera marina, especially under low-light conditions. Several measures for growth, but not survival, were affected negatively by the combination of elevated $\mathrm{NH}_{4}{ }^{+}$concentrations and low light. Our experiment lasted only for $5 \mathrm{wk}$, but the sucrose reserves were almost completely depleted in lowlight plants by the end of the experiment. We suggest that continued exposure to these conditions would have reduced survival substantially. The most vulnerable plants will therefore be those living in deeper waters close to their depth limit or those shaded by phytoplankton, epiphytes or drifting macroalgae. Light attenuation in the water column is the main predictor of eelgrass depth limits, but studies on the relationship between Secchi depth, light attenuation and seagrass depth limits often tend to overestimate predicted depth limits in eutrophic areas with a high turbidity (Duarte et al. 2007). Krause-Jensen et al. (2011) showed that sediment characteristics such as a high content of organic matter, total $\mathrm{N}$, total $\mathrm{P}$ and hydrogen sulphide could partly explain why observed depth limits of eelgrass were lower than predicted in Danish coastal waters. Elevated concentrations of $\mathrm{NH}_{4}{ }^{+}$ near the bottom may also explain why the depth limits are lower than predicted from the light environment alone. Although the concentrations of $\mathrm{NH}_{4}{ }^{+}$ in the water column are typically low $(<2 \mu \mathrm{M})$ during summer, little is known about the concentrations in the bottom water close to the sediment. Fast decomposition of sediment organic matter and anoxia may stimulate the release of sediment $\mathrm{NH}_{4}{ }^{+}$ into the water during summer. Conley et al. (2007) showed that the net flux of $\mathrm{NH}_{4}{ }^{+}$from sediment to the bottom water could reach ca. $300 \mu \mathrm{mol} \mathrm{m}^{-2} \mathrm{~h}^{-1}$ during mid-summer in shallow Skive Fjord (Denmark). This efflux caused the concentration of $\mathrm{NH}_{4}{ }^{+}$ in the bottom water to increase from $<5 \mu \mathrm{M}$ to
50-100 $\mu \mathrm{M}$ for $1 \mathrm{mo}$, while no increase was detected in the surface waters. The $\mathrm{NH}_{4}{ }^{+}$concentration in the bottom water surrounding eelgrass plants may thus be significantly higher than indicated from water samples taken further up in the water column, and they may reach concentrations at which the performance of eelgrass is affected.

Coastal eutrophication is often followed by accumulation of drifting macroalgae that may cover entire seagrass meadows (e.g. Rasmussen et al. 2013). Mass accumulation of macroalgae in seagrass meadows typically occurs in summer and may impair light availability, but it also may cause an increase in the concentrations of $\mathrm{NH}_{4}{ }^{+}$within and below the mat. Field studies by Bierzychudek et al. (1993) and Hauxwell et al. (2001) demonstrated that the $\mathrm{NH}_{4}{ }^{+}$ concentration increased from a few $\mu \mathrm{M}$ in the water above the algal mats to more than $100 \mu \mathrm{M}$ at the bottom of mats with a thickness of $20-30 \mathrm{~cm}$. Similar results have been obtained in laboratory experiments using mats of the green alga Chaetomorpha linum (e.g. Krause Jensen et al. 1999, McGlathery et al. 1997). These studies show that seagrasses can be exposed to conditions of low light and very high $\mathrm{NH}_{4}{ }^{+}$concentrations in summer when more optimal conditions (i.e. high insolation and low $\mathrm{NH}_{4}{ }^{+}$concentration) otherwise are expected. Whether algal mats may cause a serious impact on the seagrasses may to a large extent depend on the duration of the algal cover.

In summary, high, but ecologically relevant $\mathrm{NH}_{4}{ }^{+}$ concentrations had a negative effect on eelgrass performance. Net photosynthesis was not affected by $\mathrm{NH}_{4}{ }^{+}$enrichment, but other measures of growth were affected negatively by elevated $\mathrm{NH}_{4}{ }^{+}$concentrations. The negative effects were much more apparent in plants cultivated under low light than under high light and the adverse effects were correlated to a substantial decrease in sucrose and starch reserves. The negative effect of elevated $\mathrm{NH}_{4}{ }^{+}$concentrations on eelgrass thus seems to be related to an imbalance in the $\mathrm{C}$ economy of the plant.

Acknowledgements. This study is part of the REELGRASS (09-063190/DSF) project funded by the Danish Strategic Science Foundation. Additional support was provided by the Spanish national projects CTM2008-00012 (iMacHydro) and CTM2011-24482 (SEA-LIVE). B.V. was supported by a FPI grant from Ministerio de Economía y Competitividad. We thank 3 anonymous referees for their constructive comments on an early version of the manuscript. Thanks also to Rikke Guttesen and Anne Faarborg for valuable help with many of the chemical analyses. This is CEIMAR journal publication no. 36 . 


\section{LITERATURE CITED}

Alcoverro T, Romero J, Duarte CM, López NI (1997) Spatial and temporal variations in nutrient limitation of seagrass Posidonia oceanica growth in the NW Mediterranean. Mar Ecol Prog Ser 146:155-161

Anderson MJ, Gorley RN, Clarke KR (2008) PERMANOVA+ for PRIMER. Guide to software and statistical methods. PRIMER-E Ltd, Plymouth

Bierzychudek A, D'Avanzo C, Valiela I (1993) Effects of macroalgae, night and day, on ammonium profiles in Waquoit Bay. Biol Bull (Woods Hole) 185:330-331

> Borum J, Pedersen O, Greve TM, Frankovich TA, Zieman JC, Fourqurean JW, Madden CJ (2005) The potential role of plant oxygen and sulphide dynamics in die-off events of the tropical seagrass, Thaliassia testudinum. J Ecol 93:148-158

> Bower CE, Holm-Hansen T (1980) A salicylate-hypochlorite method for determining ammonia in seawater. Can J Fish Aquat Sci 37:794-798

Britto DT, Kronzucker HJ (2002) $\mathrm{NH}_{4}{ }^{+}$toxicity in higher plants: a critical review. J Plant Physiol 159:567-584

> Britto DT, Siddiqui MY, Glass ADM, Kronzucher HJ (2001) Futile transmembrane $\mathrm{NH}_{4}{ }^{+}$cycling: a cellular hypothesis to explain ammonium toxicity in plants. Proc Natl Acad Sci USA 98:4255-4258

> Brun FG, Hernández I, Vergara JJ, Peralta G, Pérez-Lloréns JL (2002) Assessing the toxicity of ammonium pulses to the survival and growth of Zostera noltii. Mar Ecol Prog Ser 225:177-187

Brun FG, Olivé I, Malta E, Vergara JJ, Hernández I, PérezLloréns JL (2008) Increased vulnerability of Zostera noltii to stress caused by low light and elevated ammonium levels under phosphate deficiency. Mar Ecol Prog Ser 365:67-75

> Bryars S, Collings G, Miller D (2011) Nutrient exposure causes epiphytic changes and coincident declines in two temperate Australian seagrasses. Mar Ecol Prog Ser 441: 89-103

Burkholder JM, Mason KM, Glasgow HB Jr (1992) Watercolumn nitrate enrichment promotes decline of eelgrass Zostera marina: evidence from seasonal mesocosm experiments. Mar Ecol Prog Ser 81:163-178

Burkholder JM, Tomasko DA, Touchette BW (2007) Seagrasses and eutrophication. J Exp Mar Biol Ecol 350: $46-72$

- Christianen MJA, van der Heide T, Bouma TJ, Roelofs JGM, van Katwijk MM, Lamers LPM (2011) Limited toxicity of $\mathrm{NH}_{x}$ pulses on an early and late successional tropical seagrass species: Interactions with $\mathrm{pH}$ and light level. Aquat Toxicol 104:73-79

> Conley DJ, Kaas H, Møhlenberg F, Rasmussen B, Windolf J (2000) Characteristics of Danish Estuaries. Estuaries 23: 820-837

> Conley DJ, Carstensen J, Ærtebjerg G, Christensen PB, Dalsgaard T, Hansen JLS, Josefson AB (2007) Long-term changes and impacts of hypoxia in Danish coastal waters. Ecol Appl 17:S165-S184

Costanza R, d'Arge R, de Groot R, Farber S and others (1997) The value of the world's ecosystem services and natural capital. Nature 387:253-260

> Dennison WC, Aller RC, Alberte RS (1987) Sediment ammonium availability and eelgrass (Zostera marina) growth. Mar Biol 94:469-477

> Dominguez-Valdivia MD, Aparicio-Tejo PM, Lamsfus C,
Cruz C, Martins-Loução MA, Moran JF (2008) Nitrogen nutrition and antioxidant metabolism in ammoniumtolerant and -sensitive plants. Physiol Plant 132:359-369

> Dortch Q, Clayton JR, Thoresen SS, Ahmed SI (1984) Species differences in accumulation of nitrogen pools in phytoplankton. Mar Biol 81:237-250

Duarte CM (2000) Marine biodiversity and ecosystem services: an elusive link. J Exp Mar Biol Ecol 250:117-131

Duarte CM, Marbà N, Krause-Jensen D, Sánchez-Camacho M (2007) Testing the predictive power of seagrass depth limit models. Estuaries Coasts 30:652-656

Grasshoff K, Ehrhardt M, Kremling K (1983) Methods of seawater analysis, 2nd edn. Verlag Chemie, Weinheim

Greve TM, Borum J, Pedersen O (2003) Meristematic oxygen variability in eelgrass (Zostera marina). Limnol Oceanogr 48:210-216

- Harlin MM, Thorne-Miller B (1981) Nutrient enrichment of seagrass beds in a Rhode Island coastal lagoon. Mar Biol 65:221-229

Hauxwell J, Cebrián J, Furlong C, Valiela I (2001) Macroalgal canopies contribute to eelgrass (Zostera marina) decline in temperate estuarine ecosystems. Ecology 82: 1007-1022

Hernández I, Peralta G, Pérez-Lloréns JL, Vergara JJ, Niel FX (1997) Biomass and dynamics of growth of Ulva species in Palmones River Estuary. J Phycol 33:764-772

Holmer M, Bondgaard EJ (2001) Photosynthesis and growth response of eelgrass to low oxygen and high sulfide concentrations during hypoxic events. Aquat Bot 70:29-38

> Invers O, Kraemer GP, Pérez M, Romero J (2004) Effects of nitrogen metabolism and carbon reserves in the temperate seagrass Posidonia oceanica. J Exp Mar Biol Ecol 303: 97-114

Jones CG, Hare JD, Compton SJ (1989) Measuring plant protein with the Bradford assay. Evaluation and standard method. J Chem Ecol 15:979-992

Krause-Jensen D, Christensen PB, Rysgaard S (1999) Oxygen and nutrient dynamics within mats of the filamentous macroalga Chaetomorpha linum. Estuaries 22:31-38

> Krause-Jensen D, Carstensen J, Nielsen SL, Dalsgaard T, Christensen PB, Fossing H, Rasmussen MB (2011) Sea bottom characteristics affect depth limits of eelgrass Zostera marina. Mar Ecol Prog Ser 425:91-102

Lee KS, Dunton KH (2000) Effects of nitrogen enrichment on biomass allocation, growth, and leaf morphology of the seagrass Thalassia testudinum. Mar Ecol Prog Ser 196: 39-48

Liu HJ, Chang BY, Yan HW, Yu FH, Liu XX (1995) Determination of amino acids in food and feed byderivatization with 6-aminoquinolyl- $N$ hydroxysuccinimidyl carbamate and reversed-phase liquid chromatographic separation. J AOAC Int 78:736-744

> Lyons DA, Mant RC, Bulleri F, Kotta J, Rilov G, Crowe TP (2012) What are the effects of macroalgal blooms on the structure and functioning of marine ecosystems? Systematic review protocol. Environ Evid 1:7

Magalhaes JR, Huber DM, Tsai CY (1992) Evidence of increased ${ }^{15} \mathrm{~N}$-ammonium assimilation in tomato plants with exogenous $\alpha$-ketoglutarate. Plant Sci 85:135-141

Marschener H (1995) The mineral nutrition of higher plants, 2nd edn. Academic Press, London

Marsh JA, Dennison WC, Alberte RE (1986) Effects of temperature on photosynthesis and respiration in eelgrass (Zostera marina L.). J Exp Mar Biol Ecol 101:257-267

McGlathery KJ (2001) Macroalgal blooms contribute to the 
decline of seagrass in nutrient-enriched coastal waters. J Phycol 37:453-456

McGlathery KJ, Krause-Jensen D, Rysgaard S, Christensen PB (1997) Patterns of ammonium uptake within dense mats of the filamentous macroalga Chaetomorpha linum. Aquat Bot 59:99-115

Murray L, Dennison WC, Kemp WM (1992) Nitrogen versus phosphorus limitation for growth of an estuarine population of eelgrass (Zostera marina L.). Aquat Bot 44: 83-100

Nejrup LB, Pedersen MF (2008) Effects of salinity and water temperature on the ecological performance of Zostera marina. Aquat Bot 88:239-246

Olesen B, Sand-Jensen K (1993) Seasonal acclimatization of eelgrass Zostera marina growth to light. Mar Ecol Prog Ser 94:91-99

Olivé I, García-Sánchez MP, Brun FG, Vergara JJ, PérezLloréns JL (2009) Interactions of light and organic matter under contrasting resource simulated environments: the importance of clonal traits in the seagrass Zostera noltii. Hydrobiologia 629:199-208

Orth RJ (1977) Effect of nutrient enrichment on growth of the eelgrass, Zostera marina, in the Chesapeake Bay, Virginia, USA. Mar Biol 44:187-194

Orth RJ, Carruthers TJB, Dennison WC, Duarte CM and others (2006) A global crisis for seagrass ecosystems. Bioscience 56:987-996

Pedersen MF (1995) Nitrogen limitation of photosynthesis and growth: comparison across aquatic plant communities in a Danish estuary (Roskilde Fjord). Ophelia 41: 261-272

Pedersen MF, Borum J (1993) An annual nitrogen budget for a seagrass Zostera marina population. Mar Ecol Prog Ser 101:169-177

Peralta G, Bouma TJ, van Soelen J, Pérez-Lloréns JL, Hernández I (2003) On the use of sediment fertilization for seagrass restoration: a mesocosm study on Zostera marina L. Aquat Bot 75:95-110

Pérez M, Invers O, Ruiz JM, Frederiksen MS, Holmer M (2007) Physiological responses of the seagrass Posidonia oceanica to elevated organic matter content in sediments: An experimental assessment. J Exp Mar Biol Ecol 344:149-160

Quinn GP, Keough MJ (2002) Experimental design and data analysis for biologists. Cambridge University Press, Cambridge

Rasmussen JR, Pedersen MF, Olesen B, Nielsen SL, Pedersen TM (2013) Temporal and spatial dynamics of

Editorial responsibility: Just Cebrian,

Dauphin Island, Alabama, USA ephemeral drift-algae in eelgrass, Zostera marina, beds. Estuar Coast Shelf Sci 119:167-175

Rubio L, Linares-Rueda A, García-Sánchez MJ, Fernández JA (2007) Ammonium uptake kinetics in root and leaf cells of Zostera marina L. J Exp Mar Biol Ecol 352: $271-279$

Sand-Jensen K (1975) Biomass, net production and growth dynamics in an eelgrass (Zostera marina L.) population in Vellerup Vig, Denmark. Ophelia 14:185-201

> Sand-Jensen K, Borum J (1991) Interactions among phytoplankton, periphyton, and macrophytes in temperate freshwaters and estuaries. Aquat Bot 41:137-175

> Short FT, Wyllie-Echeverria S (1996) Natural and humaninduced disturbance of seagrasses. Environ Conserv 23: $17-27$

Short FT, Burdick DM, Kaldy JE (1995) Mesocosm experiments quantify the effects of eutrophication on eelgrass, Zostera marina. Limnol Oceanogr 40:740-749

Short FT, Polidoro B, Livingstone SR, Carpenter KE and others (2011) Extinction risk assessment of the world's seagrass species. Biol Conserv 144:1961-1971

Stryer L (1981) Biochemistry, 2nd edn. WH Freeman \& Company, San Francisco, CA

Thursby GB, Harlin MM (1982) Leaf-root interaction in the uptake of ammonia by Zostera marina. Mar Biol 72: 109-112

> Valiela I, McClelland J, Hauxwell J, Behr PJ, Hersh D, Foreman K (1997) Macroalgal blooms in shallow estuaries: controls and ecophysiological and ecosystem consequences. Limnol Oceanogr 42:1105-1118

van der Heide T, Smolders A, Rijkens B, van Nes EH, van Katwijk MM, Roelofs J (2008) Toxicity of reduced nitrogen in eelgrass (Zostera marina) is highly dependent on shoot density and $\mathrm{pH}$. Oecologia 158:411-419

van Katwijk MM, Vergeer LHT, Schmitz GHW, Roelofs JGM (1997) Ammonium toxicity in eelgrass Zostera marina. Mar Ecol Prog Ser 157:159-173

> Villazán B, Brun FG, Jiménez-Ramos R, Pérez-Lloréns JL, Vergara JJ (2013) Interaction between ammonium and phosphate uptake rates in the seagrass Zostera noltii. Mar Ecol Prog Ser 488:133-143

Waycott M, Duarte CM, Carruthers TJB, Orth RJ and others (2009) Accelerating loss of seagrasses across the globe threatens coastal ecosystems. Proc Natl Acad Sci USA 106:12377-12381

> Wintermans JFGM, De Mots A (1965) Spectrophotometric characteristics of chlorophylls $a$ and $b$ and their pheophytins in ethanol. Biochim Biophys Acta 109:448-453

Submitted: May 2, 2013; Accepted: August 13, 2013

Proofs received from author(s): November 10, 2013 